\title{
凝固の線溶におよぼす影響
}

\author{
高田 明和* 高田由美子*
}

\section{Influence of coagulation on fibrinolysis}

\author{
Akikazu TAKADA* and Yumiko TAKADA*
}

Key words : plasminogen, $\alpha_{2}$ plasmin inhibitor $\left(\alpha_{2} \mathrm{PI}\right), \alpha_{2}$ macroglobulin $\left(\alpha_{2} \mathrm{M}\right)$, tranexamic acid

Glu-plasminogen (Glu-plg) was better activated by urokinase (UK) in the presence of fibrin or tranexamic acid. Lys-plg was not influenced by their presence, and acid treated plg (A-plg) was less activated by UK in their presence. Inhibitory effects of $\alpha_{2}$ plasmin inhibitor $\left(\alpha_{2} \mathrm{PI}\right)$ on plasmin were counteracted by fibrin, tranexamic acid and $\alpha_{2}$ macroglobulin $\left(\alpha_{2} \mathrm{M}\right)$. Since fibrin, tranexamic acid, and $\alpha_{2}$ PI bind with lysine binding sites of plasminogen, there are competitions for these sites among $\alpha_{2} \mathrm{PI}$, fibrin, and tranexamic acid.

\section{はじめに}

凝固と線溶とは密接な関係にある。われわれ は最近凝固がおこると plasminogen の立体構造 に変化が抢てり, activator により活性化されや すくなるととを示した ${ }^{12)}$. 今回は plasminogen の種々の type が凝固の際に urokinase (UK) により活性化される程度がいかに変化をうける かを示す.

\section{I. 方 法}

1. Glu-plasminogen (Glu-plg)：保存血漿を 透析後, aprotinin の存在下で lysine-Sepharose を通して得た。 Casein unit は Robbins and Summaria の方法により計算した ${ }^{3)}$.
2. $\quad$ Plg I と plg II : plg I と plg II は $3 \times 14$ $\mathrm{cm}$ の lysine-Sepharose のカラムに Glu-plgを のせ， 6-aminohexanoic acid の $20 \mathrm{mM}$ までの 直線濃度勾配で溶出した。 2 つの peak の内, 前に溶出したものを plg I とし，後に溶出され るあのを plg II とした.

3. 酸処理 plg (A-plg): A-plg は lysineSepharose よりの溶出に $0.1 \mathrm{M}$ の酢酸を用いて 得たあのである.

4. Lys-plg: Glu-plg を固相化 plasmin で 活性して作成した。

5. 各種 plg の分子量：SDS-gelelectrophoresisにより Glu-plgは 93,000, plg I は93,000, plg II は 89,000, Lys-plg は 86,000, A-plg は 86,000 と 62,000 の分子量をあつととが示され

* 浜松医科大学第二生理学教室 〔干 431-31 浜松市半田町3600], Department of Physiology, Hamamatsu University, School of Medicine, Hamamatsu, Japan. 

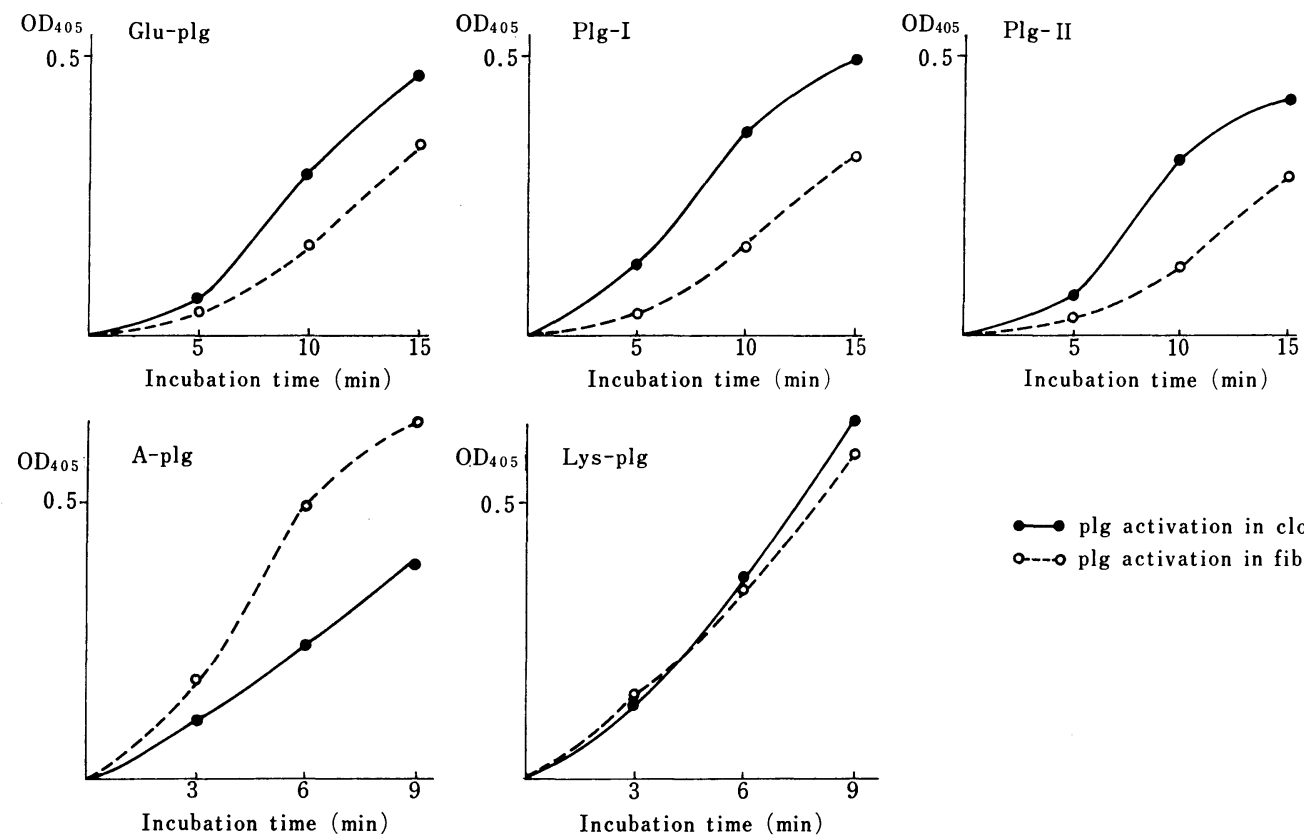

$\longrightarrow$ plg activation in clot.

o---o plg activation in fibrinogen.

Fig. 1 Effects of clot formation on the activation of various plasminogens by UK.

$\mathbf{A}$

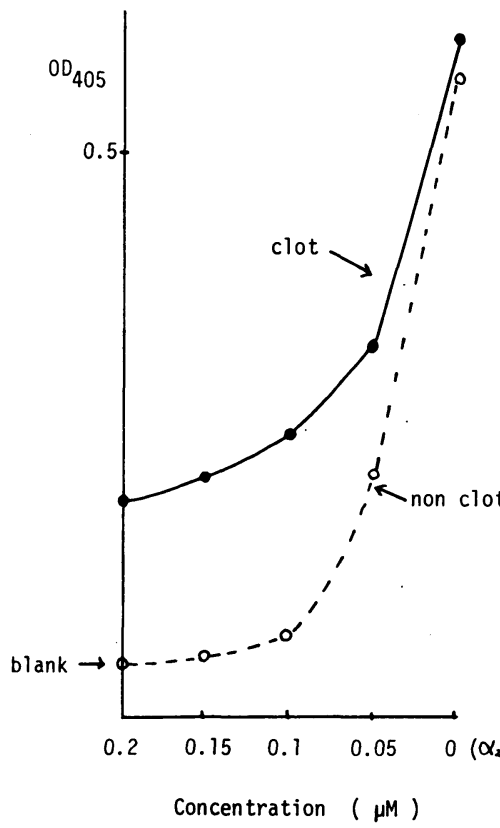

B

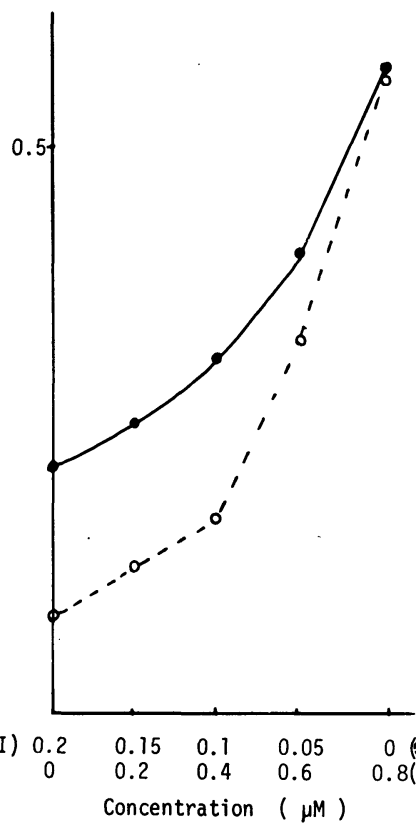

C

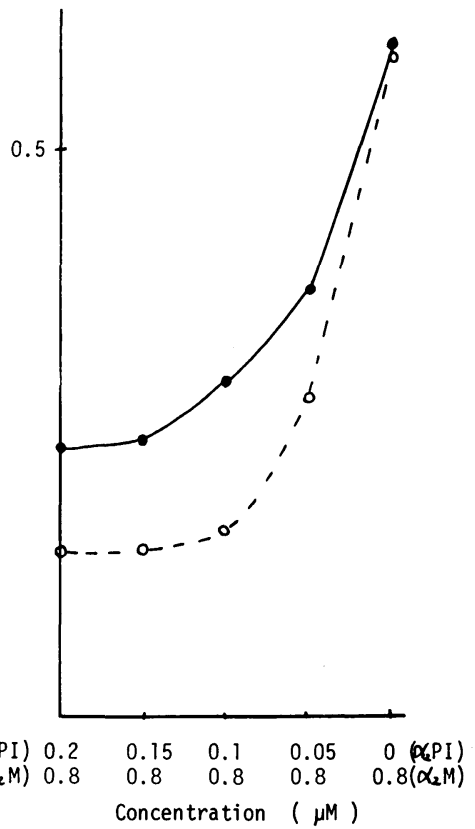

Fig. 2 Effects of $\alpha_{2} \mathrm{PI}$ and $\alpha_{2} \mathrm{M}$ on the activation of plasminogen by UK in the presence or absence of clot.

A Effects of various concentration of $\alpha_{2}$ PI.

B Effects of the mixture of various concentration of $\alpha_{2} \mathrm{PI}$ and $\alpha_{2} \mathrm{M}$.

C Effects of the mixture of various concentration of $\alpha_{2} \mathrm{PI}$ and $0.8 \mu \mathrm{M}$ of $\alpha_{2} \mathrm{M}$. 
た.

\section{II. 結果亡考察}

(1) $0.1 \mathrm{~m} l$ の plg (0.1casein unit: $0.1 \mathrm{c}$. u.), $0.1 \mathrm{~m} l$ のヒト fibrinogen (KABI, 0.6 $\mathrm{mg}), 0.05 \mathrm{~m} l$ のヒト thrombin $(0.5 \mathrm{u})$ また は buffer, $0.2 \mathrm{~m} l$ の tris buffer を $0.5 \mathrm{~m} l$ の $\mathrm{S}-2251(100 \mu \mathrm{g})$ と混合し，時間を扤いて1.5 $\mathrm{m} l$ の $50 \%$ 酢酸を加え, 反応を止め, 溶液中 のプラスミン活性を合成基質S-2251を用いて 測定した. 図 1 はこの結果を示すもので, Glu-plg, plg I , plg II は凝固時の方が凝固の ない時よりUKにより活性化され易い. A-plg はむしろ凝固時の方が活性化されにくくな る. 一方, Lys-plg は凝固の存在と関係なく 活性化された。

(2) 上記の混液の tris-buffer 飞種々濃度の $\alpha_{2} \mathrm{PI} ， \alpha_{2} \mathrm{M}$ ，または両者を加元，凝固時のプ ラスミン活性に対する $\alpha_{2} \mathrm{M} ， \alpha_{2} \mathrm{PI}$ の作用を しらべた.

図 $2 \mathrm{~A}$ は種々濃度の $\alpha_{2} \mathrm{PI}$ を凝固時, 非凝 固時に加え，Glu-plg よりUKにより活性化さ れた plasmin の S-2251 水解能をしらべたもの である. $0.2 \mu \mathrm{M}$ の $\alpha_{2} \mathrm{PI}$ の存在下では凝固のな い時（non-clot）は plasmin 活性は完全に阻止 される.一方凝固の存在時にはある程度plasmin 活性があらわれ，凝固は $\alpha_{2} \mathrm{PI}$ の作用に拮抗す るととがわかる．乙れに種々濃度の $\alpha_{2} \mathrm{M}$ を加 えたものが図 2 B である， $\alpha_{2} \mathrm{PI}$ 亿種々濃度の $\alpha_{2} \mathrm{M}$ を加えていくと，たとえば $0.1 \mu \mathrm{M}$ の $\alpha_{2}$ $\mathrm{PI}$ と $0.4 \mu \mathrm{M}$ の $\alpha_{2} \mathrm{M}$ の存在下では非凝固時あ ある程度の $\mathrm{S}-2251$ 水解を示す. $\alpha_{2} \mathrm{M}$ にとり込 まれた plasmin は S-2251 を水解する能力をす ち，さらに $\alpha_{2} \mathrm{PI}$ などの inhibitor によりもは や阻害されなくなるので，乙の部分の活性は $\alpha_{2} \mathrm{M}$ にとり込まれた plasmin によると思われ る. 図 $2 \mathrm{C} 0.8 \mu \mathrm{M}$ の $\alpha_{2} \mathrm{M}$ を $\alpha_{2} \mathrm{PI}$ の他に 加えたあので， $0.2 \mu \mathrm{M}$ の $\alpha_{2} \mathrm{PI}$ 存在の非凝固 時にあある程度の plasmin 活性がみられる.す なわち $\alpha_{2} \mathrm{M}$ の濃度をませば $\alpha_{2} \mathrm{PI}$ と反応する plasminogen の量は減少する.凝固がおこれば さらに $\alpha_{2} \mathrm{PI}$ の作用は少くなる.

(3) 図了は $\alpha_{2} \mathrm{PI}$ と tranexamic acidの拮抗

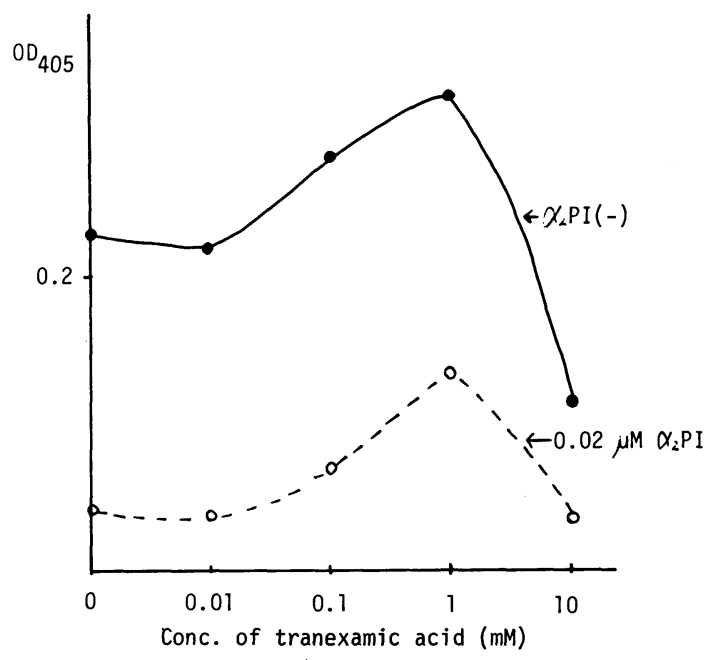

Fig. 3 Effects of various amounts of tranexamic acid on the activation of Glu-plasminogen by UK.

" $0.02 \mu \mathrm{M} \quad \alpha_{2} \mathrm{PI}$ " indicates the hydrolysis of S-2251 in the presence of $0.02 \mu \mathrm{M}$ of $\alpha_{2} \mathrm{PI}$. " $\alpha_{2} \mathrm{PI}(-)$ " indicates the hydrolysis of S-2251 in the absence of $\alpha_{2}$ PI.

作用を示す. $0.1 \mathrm{~m} l$ の Glu-plg (0.1c.u.)， 0.1 $\mathrm{m} l$ の UK (100u), $0.1 \mathrm{~m} l$ の tranexamic acid, $0.2 \mathrm{~m} l$ の $\alpha_{2} \mathrm{PI}$ 溶液 $(0.02 \mu \mathrm{M})$ を $0.5 \mathrm{~m} l$ の $\mathrm{S}-2251$ と混合, $37^{\circ} \mathrm{C}$ で15分間 incubate した。 $\alpha_{2} \mathrm{PI}$ のない所では Glu-plg は tranexamic acidの濃度をますととすに活性化されやすくな り，1mM の所で peak に達する.さらに tranexamic acid の濃度をますと, plg の活性化は やや抑制される， $\alpha_{2} \mathrm{PI}$ の存在下では plasmin の作用は抑制されるが，1mM の tranexamic acid の存在下では抑制が少なく, plasmin の作 用があらわれる。

以上の現象は plg の lysine binding site (L BS）の反応により説明されうる. Plgには 5 6 この LBS があり, Glu-plg の LBS に tranexamic acid や fibrin が結合すると Glu-plg は立体構造に変化をおこし，UK 等により非常 に活性化され易くなる。一方 Lys-plg は tranexamic acid 等との結合で立体構造に変化を おこさない. A-plgは degradate した plgで, tranexamic acid 等が結合すると，むしろ UK により活性化されにくくなる， $\alpha_{2} \mathrm{PI}$ む LBS に 
$11: 640$

より plgまたは plasmin と結合するので fibrin や tranexamic acid と拮抗する.

\section{結 論}

凝固時には Glu-plg はUK により活性化さ れやすくなり，Lys-plg は変化をうけず, A-plg はむしろ活性化されにくくなる. fibrin, tranexamic acid, $\alpha_{2} \mathrm{M}$ は $\alpha_{2} \mathrm{PI}$ の作用に拮抗する.

\section{文献}

1) Takada, A., Ohashi, H., Matsuda, H. and Takada, Y.: Effects of tranexamic acid, cis-AMCHA, and 6-aminohexanoic acid on
血 液 と脈管 第 11 巻第 4 号 the activation rate of plasminogen by urokinase in the presence of clot. Thrombos. Res., 14; 915 923, 1979.

2) Takada, A., Urano, T. and Takada, Y.: Influence of coagulation on the activation of plasminogen by streptokinase and urokinase. Thrombos. Haemostas., 42; 901 908, 1979.

3) Robbins, K.C. and Summaria, L. : Purification of human plasminogen and plasmin by gel filtration on sephadex and chromatography on diethylaminoethyl-sephadex. J. Biol. Chem., 238; 952 962, 1963.

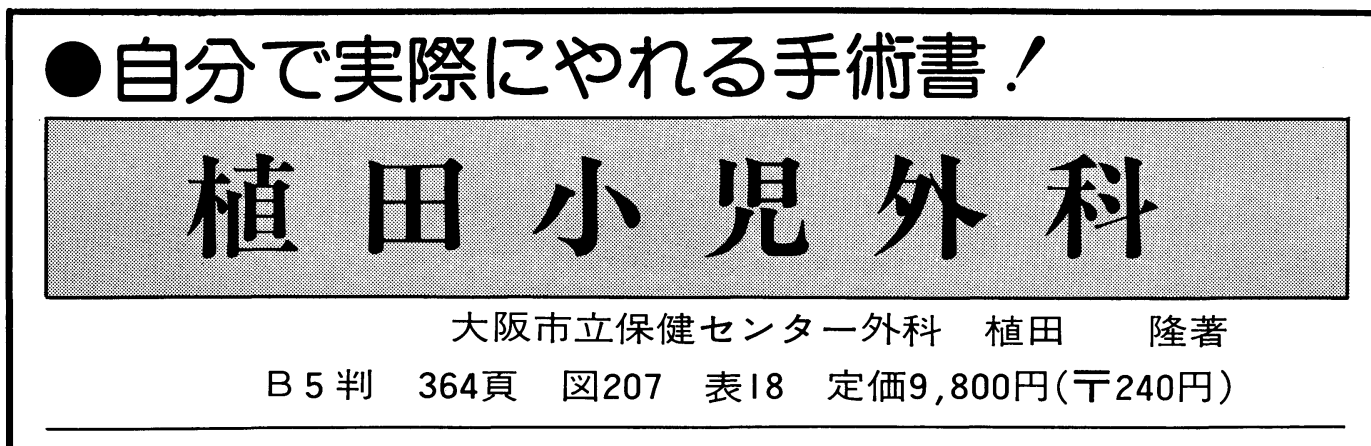

